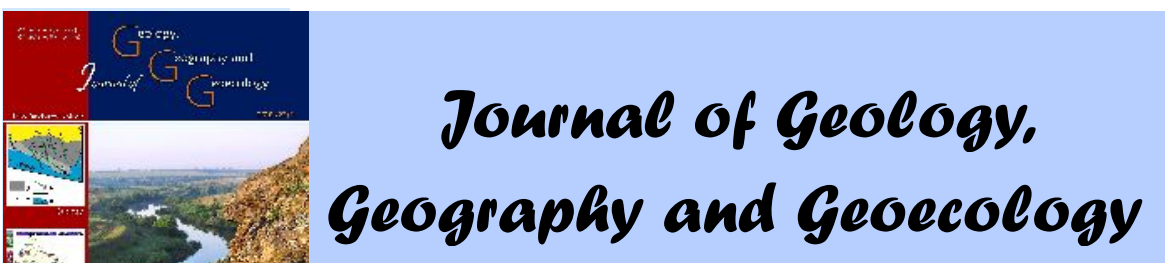

Journal home page: geology-dnu-dp.ua

\title{
Chemical composition of different types of natural waters in Ukraine
}

\author{
V. . Khilchevskyi ${ }^{1}$, S. . Kurylo ${ }^{1}$, N.P. Sherstyuk ${ }^{2}$ \\ ${ }^{1}$ Taras Shevchenko National University of Kyiv, Kyiv, Ukraine, e-mail: hilchevskiy@ukr.net \\ ${ }^{2}$ Oles Gonchar Dnipro National University, Dnipro, Ukraine, e-mail: sherstuknp@gmail.com
}

Received 23.04.2018;

Received in revised form 05.05.2018;

Accepted 29.05.2018

Abstract. The results of studies of the chemical composition in various types of natural waters of the territory of Ukraine - atmospheric precipitation, surface (river and lake), groundwaters and sea waters are comprehensively summarized and presented for the territory of Ukraine in this paper. The chemical composition of Ukraine's natural waters (rivers, lakes, underground aquifers, seas) is the result of the interaction of a combination of natural factors, as well as their location, mainly in the temperate climatic zone. The average long-term mineralization of atmospheric precipitation is usually in the range of $20-40 \mathrm{mg} / \mathrm{l}$, its chemical composition is predominantly sulfate magnesium-calcium. For the chemical composition of water in the small and medium rivers of Ukraine, hydrochemical zoning is observed in the direction from the northwest to the south-east of the country. Mineralization of river waters also increases in this direction (from 200-300 mg/l to 1,500-3,000 mg/l and more). The composition of the water varies from bicarbonate calcium in the north and west to sodium chloride in the south and southeast. The value of mineralization of lake water varies within very wide limits. There are lakes with very fresh water and low salinity (30 mg/l - small lakes of glacial origin in the Ukrainian Carpathians), and lakes whose water has a mineralization of more than $100 \mathrm{~g} / \mathrm{l}$ (salt lakes of the Crimea). In the chemical composition of groundwater, the territory of Ukraine mainly exhibits vertical hydrochemical zoning, which manifests itself in the separation of zones of intensive or difficult water exchange. Hydrocarbonate or sulfate waters with a small mineralization (up to $1.0 \mathrm{~g} / \mathrm{l}$ ) are characteristic for the zone of active water exchange. Highly mineralized (50-300 g/l and more) chloride, sodium and chloride-sodiumcalcium waters are common in a zone of hindered water exchange. The ionic composition of the Black Sea water has all the characteristic features of ocean waters but differs from them in relative poverty with ions of chlorine and sodium, the average salinity of the Black Sea waters is $18-19 \%$. In the narrow coastal zone near the mouths of large rivers (the Danube, the Dniester, the Southern Bug, the Dnieper) a decrease in the salinity of the Black Sea waters (up to 5-10\%) is observed. The main factors that determine the salinity regime in the Azov Sea (10-13\%o) are the inflow of saline Black Sea and fresh river (the Don and the Kuban rivers) waters that are mixed in the Azov Sea, as well as the arrival of atmospheric precipitation.

Key words: chemical composition, atmospheric precipitation, surface waters, groundwaters, seawaters.

\section{імічний скл д різних типів природних вод кр їни}

\author{
. . ільчевський ${ }^{1}$, . . урило ${ }^{1}$, . . ерстюк $^{2}$ \\ 1 иӥвський н ціон льний університет імені $р$ с евченк, иїв, кр їн \\ 2 ніпровський н ціон льний університет імені леся онч $p$, ніпро, кр їн
}

нот ція. ля території кр їни комплексно уз г льнено і викл дено результ ти досліджень хімічного скл ду різних типів природних вод території кр їни - тмосферних оп дів, поверхневих (річкових і озерних), підземних і морських вод. ередня б г торічн мінер ліз ція тмосферних оп дів з звич й у меж х $20-40$ мг/дм³ м гнієво-к льцієвий. ля хімічного скл ду води м лих і середніх річок кр їни спостеріг ється гідрохімічн зон льність у н прямку з північного з ходу н південний схід території кр їни. цьому н прямку збільшується і мінер ліз ція річкових вод (від $200-300$ мг/дм³ до $1500-3000$ мг/дм і більше). кл д вод змінюється і від гідрок рбон тного к льцієвого н півночі і з ході до хлоридного н трієвого н півдні і південному сході. еличин мінер ліз ції води озер змінюється в широких меж х. p пляються озер з дуже прісною водою і низькою мінер ліз цією $(30$ мг/дм³), і т кі, вод яких м є мінер ліз цію пон д 100 г/дм³ . хімічному скл ді підземних вод н території кр їни в основному проявляється вертик льн гідрохімічн зон льність. ля зони ктивного водообміну х р ктерні гідрок рбон тні бо сульф тні води з невеликою мінер ліз цією (до 1 г/дм³ $)$. зоні утрудненого водообміну поширені високомінер лізов ні $(50-300$ г/дм³ і більше) хлоридні н трієві і хлоридні н трієво-к льцієві води. онний скл д води орного моря близький з скл дом до вод оке ну, ле відрізняється від них низьким вмістом іонів хлору і н трію, середня солоність вод орного моря - $18-19 \%$. вузькій прибережній смузі поблизу гирл великих річок спостеріг ється зниження солоності чорноморських вод (до $5-10 \%$ ). сновні ф ктори, які визн ч ють режим 
солоності в зовському морі $(10-13 \%$ ), - це приплив солоних чорноморських і прісних річкових вод, які змішуються в зовському морі, т кожн дходження тмосферних оп дів.

лючові слов : хімічний скл д, тмосферні оп ди, поверхневі води, підземні води, морські води

Introduction. A water object is a natural or artificially created element of the environment where waters are concentrated: seas, estuaries, rivers, creeks, lakes, reservoirs, ponds, canals and aquifers (Vodnyi kodeks Ukrainy, 1995). Natural waters filling water bodies are a complex of dissolved compounds, the formation of which takes place under the influence of natural (physiographic factors, primarily climatic and soil, geological, physicochemical, biological) and anthropogenic factors. The influence of these factors on natural waters has its own regularities and differences, which appears both at the level of the natural zones and regions, and on certain types of water bodies: rivers, lakes, underground aquifers, seas. It is also important to know the chemical composition of atmospheric precipitation, which takes an active part in the sustenance of water bodies. There is a considerable interest in studies within the territory of a particular country, where the diversity of the chemical composition of various types of natural waters is fully manifested (Khil'chevskii, Chebot'ko, 1994).

The history of hydrochemical research in Ukraine. Systematic observations of the chemical composition of river, lake, underground and sea waters in Ukraine began in the 1930s with the network of observation of the hydrometeorological service. Monitoring data on the chemical composition of surface waters have been published in the Hydrological Yearbooks, since 1968 in the quarterly "Hydrochemical Bulletins," and since 1984 in the "Annual Data on the Quality of the Surface Waters of Ukraine." A significant contribution to the foundation and development of hydrochemical studies in Ukraine was made by scientists from the Institute of Hydrobiology of the National Academy of Sciences of Ukraine, whose studies were devoted to the formation of the hydrochemical regime of estuaries of rivers, estuaries, the Dnieper reservoirs, and to the content of heavy metals in water (Almazov, 1962; Denisova, Timchenko, Nahshina et al., 1989; Linnik, Nabivanec, 1986; Zhuravleva, 1988).

Scientists of Taras Shevchenko National University of Kyiv studied the interrelation of the chemical composition of different types of natural waters in Ukraine (Peleshenko, 1975), developed the fundamentals of ameliorative hydrochemistry (Gorjev, Peleshenko, 1991, Zakrevskiy, 1992), revealed the role of anthropogenic factors in its formation (Gorjev, Peleshenko, Khilchevskyi, 1995; Khil'chevskiy, 1994), initiated the study of the hydrochemistry of slope flow surface (Khilchevskyi, 1996), the study of hydrochemistry of the cooling reservoirs on nuclear power plants and thermal power plants (Romas, 2002), hydrochemical systems (Snizhko, 2006).

As a result of complex regional hydrogeological studies of the territory of Ukraine ,the main regularities in the formation of the chemical composition of groundwater in general, as well as mineral therapeutic waters were established (Babynec, Beljavskyj, 1973; Babynec, Borevskyj, Shestopalovet al., 1979; Shestopalov, 2009; Ohnianyk, 2000).

A number of works by the staff of the Ukrainian Hydrometeorological Institute of the NAS of Ukraine (Osadchyi, Nabyvanets, Osadchaet al., 2008; Osadchyy et al., 2016) are devoted to experimental research and modeling of the migration of chemical substances in surface waters. At the Marine Hydrophysical Institute of the National Academy of Sciences of Ukraine scientists studied issues related to ocean hydrochemistry and the physical nature of formation or destruction of chemical compounds in seawater (Eremeeva, Eremeev, Bezborodov, 1984). Detailed hydrochemical (Skopincev, 1975) and geochemical (Mitropolskiy, Bezborodov, Ovsyanyiy, 1982) studies of the Black and the Azov Seas provide an opportunity to solve problems of monitoring, modeling and forecasting the condition of water basins.

The statement of the problem and source materials. The main purpose of this publication is to provide a comprehensive description of the chemical composition of various types of natural waters on the territory of Ukraine-atmospheric precipitation, surface waters (river and lake), groundwaters and sea waters. The main attention is paid to the basic ions, which include $\mathrm{HCO}_{3}{ }^{-}, \mathrm{SO}_{4}{ }^{2-} \cdot \mathrm{Cl}^{-}, \mathrm{Ca}^{2+}, \mathrm{Mg}^{2+}, \mathrm{Na}^{+}$, $\mathrm{K}^{+}$, and to the index of total mineralization.

To solve this problem, we used data on the chemical composition of Ukraine's natural waters, which derives from: 1) the result of the authors'own research; 2) analysis of published sources.

Results of the research.Precipitation. There is up to $650 \mathrm{~mm} /$ year of precipitation in the north-west of Ukraine, up to $300 \mathrm{~mm} / \mathrm{year}$ - in the south, in the Ukrainian Carpathians - up to $1,600 \mathrm{~mm} /$ year. The first studies of the chemical composition of atmospheric precipitations (AP) in Ukraine were made at the beginning of the 20th century.

The systematic sampling of APs at the network of meteorological stations of the hydrometeorological service of the former USSR began in 1958 
in connection with the implementation of works under the programme of the International Geophysical Year (IGY). After the completion of the IGY, the studies of the chemical composition of APs received further development and the network of weather stations, where AO samples were sampled for chemical analysis, was significantly expanded.

Since 1963, gathering of monthly samples of the AP has been organized at the Nemishaieve meteorological stations (since 1964 transferred to the Teterev meteorological station), Berehove, Kobelyaki, Bobrynets, Loshkarivka, Odessa, Nikitsky Botanical Garden, and since 1965 in Kiev and industrial regions of Donbass - at the meteorological stations of Donetsk and Volnovakha. In addition to the monthly samples, researchers gathered samples of single APs at the Kobeliaky, Bobrynets, Loshkarivka and Odessa meteorological stations. The results of these studies are presented in the works of the following scientists (Romas, 1979, Kosovets Skavronska, Snizhko, 2009; Khilchevskyi, Kurylo, 2016), and common results are given below.

General mineralization of the AP over the territory of Ukraine usually fluctuates within 30-40 $\mathrm{mg} / \mathrm{l}$. The minimum average annual mineralization values of the AP are fixed in the zone of mixed forests in the north of the country - about $26 \mathrm{mg} / \mathrm{l}$ (Teterev), the maximum - recorded in the south of the country, at the weather station Askania-Nova - 82.4 $\mathrm{mg} / \mathrm{l}$ (Table 1).

In the chemical composition of AP, sulfates predominate among anions, and magnesium dominates among cations. The proportion of the salts of continental-anthropogenic origin in the total chemical composition of AP on the territory of Ukraine is $90-93 \%$, that of salts of marine origin $-7-10 \%$ (Khilchevskyi, Kurylo, 2016).

Table 1. Average concentrations of chemical components in Ukraine's atmospheric precipitation (by total monthly samples), mg/l.

\begin{tabular}{|c|c|c|c|c|c|c|c|c|c|c|}
\hline Weather station & $\mathrm{SO}_{4}{ }^{2-}$ & $\mathrm{Cl}^{-}$ & $3^{-}$ & $\mathrm{NO}_{3}^{-}$ & $\mathrm{Ca}^{2+}$ & $\mathrm{Mg}^{2+}$ & $\mathrm{Na}^{+}$ & $\mathrm{K}^{+}$ & $\mathrm{NH}_{4}^{+}$ & $\begin{array}{l}\text { Gen- } \\
\text { eralmin- } \\
\text { era-liza- } \\
\text { tion }\end{array}$ \\
\hline \multicolumn{11}{|c|}{ Zone of mixed forests } \\
\hline $\begin{array}{l}\text { Teterev, } \\
\text { Kiev region }\end{array}$ & 11.7 & 2.2 & 4.0 & 1.9 & 1.6 & 2.0 & 1.5 & 1.0 & 0.87 & 26.7 \\
\hline \multicolumn{11}{|c|}{ Forest-steppe zone } \\
\hline Kyiv & 14.4 & 1.4 & 11.3 & - & 0.6 & 1.3 & 0.4 & 5.9 & 0.7 & 26.3 \\
\hline $\begin{array}{c}\text { Kobelyaki, } \\
\text { Poltava region }\end{array}$ & 14.8 & 3.8 & 11.0 & 1.6 & 3.5 & 2.8 & 2.9 & 1.4 & 1.14 & 43.0 \\
\hline \multicolumn{11}{|c|}{ Steppe zone } \\
\hline $\begin{array}{c}\text { Bobrynets, } \\
\text { Kirovograd region }\end{array}$ & 14.4 & 3.1 & 14.2 & 1.8 & 4.2 & 4.1 & 2.2 & 1.0 & 1.06 & 46.1 \\
\hline $\begin{array}{c}\text { Loshkarivka, } \\
\text { Dnepropetrovsk region }\end{array}$ & 15.0 & 3.3 & 4.9 & 1.7 & 2.7 & 2.2 & 1.7 & 1.0 & 1.55 & 34.0 \\
\hline $\begin{array}{c}\text { Volnovakha, } \\
\text { Donetsk region }\end{array}$ & 16.8 & 4.3 & 6.1 & 1.7 & 3.0 & 2.8 & 3.2 & 1.4 & 1.30 & 40.6 \\
\hline Odessa & 17.5 & 7.0 & 6.9 & 2.4 & 3.5 & 2.2 & 3.8 & 1.8 & 1.27 & 46.4 \\
\hline $\begin{array}{l}\text { Askania-Nova, } \\
\text { Kherson region }\end{array}$ & 9.6 & 8.5 & 38.0 & - & 1.5 & 13.3 & 2.1 & 9.4 & - & 82.4 \\
\hline \multicolumn{11}{|c|}{ The Carpathian Mountain } \\
\hline $\begin{array}{c}\text { Beregove, } \\
\text { Transcarpathian region }\end{array}$ & 14.4 & 3.4 & 5.7 & 1.6 & 2.1 & 2.7 & 1.6 & 1.0 & 1.41 & 34.0 \\
\hline \multicolumn{11}{|c|}{ Crimean mountainous } \\
\hline $\begin{array}{l}\text { Nikitsky Botanical Gar- } \\
\text { den, } \\
\text { Autonomous Republic of } \\
\text { Crimea }\end{array}$ & 9.3 & 3.0 & 8.1 & 1.6 & 2.1 & 1.8 & 1.7 & 1.0 & 1.00 & 29.6 \\
\hline
\end{tabular}

The most probable chemical composition of the AP was determined by the formulas of the ionic composition, where the average concentrations of the components, converted into \% -equivalent form, were used. Characteristic is the considerable stability of the ion content in the AP with a significant excess of sulfates among the anions, and magnesium among the cations. Local influence on natural factors of the chemical composition of the products of agri- cultural enterprises affects the increase in hydrocarbonates and magnesium in the steppe zone (AskaniaNova) and sodium chlorides in the seaside Odessa, and anthropogenic - in increasing the content of almost all components, especially sulphates, in the industrial Donbass.

The most probable chemical composition of the AP over the territory of Ukraine in\%-equivalent form is expressed by the formula: 


\section{$\mathrm{SO}_{4} 55 \mathrm{HCO}_{3} 22 \mathrm{Cl} 18 \mathrm{NO}_{3} 5$}

$\mathrm{Mg} 38 \mathrm{Ca} 28 \mathrm{Na} 18 \mathrm{NH}_{4} 10 \mathrm{~K} 6$

In this way, the chemical composition of AP in Ukraine predominantly consists of the sulfate magnesium-calcium.

The AP of the whole territory of Ukraine is dominated by the continental-anthropogenic component and its contribution fluctuates insignificantly near the value of $90 \%$. The estimated value of the direct anthropogenic component of the chemical composition of AP is approximately $70-75 \%$. Only for chloride ions marine component is the dominative in the formation of the total content of dissolved mineral substances in atmospheric precipitation (Khilchevskyi, Kurylo, 2016.).

Rivers. In Ukraine, there are more than 63 thousand rivers with 1,103 reservoirs (Vodnyi fond Ukrainy, 2015). 98\% of the country's rivers belong to the basin of the Black and the Azov Seas, and to $2 \%$ of the territory (the Western Bug River) - to the basin the Baltic Sea. Taking into account the requirements of the EU Water Framework Directive (Directive 2000/60 / EC) in 2016, a hydrographic zoning of the territory of Ukraine was carried out. As a result, nine river basin areas were identified -the Vistula, the Danube, the Dniester, the Southern Bug, the Dnieper, the Don, and rivers of the Black Sea, the Azov Sea and the Crimea. Regions of river basins of the Dnieper, the Danube, the Dona and the Vistula are also divided into sub-basins (total 13 subbasins) (Vodnyi kodeks Ukrainy, 1995; Khilchevskyi, Grebin, 2017).

In the chemical composition of the river waters of the lowland part of the country, a clear hydrochemical zoning is observed with progress from the western and north-western to the eastern and southeastern borders of Ukraine. In the same direction, mineralization of river waters also increases (from 200-300 mg/l to 1,500-3,000 mg/l and more). Hydrochemical zoning is observed irrespective of the direction of the flow of rivers and is in some ways consistent with the boundaries of physiographic regions (Peleshenko, Zakrevskiy, Gorev et al., 1989). In the mixed forest zone fresh hydrocarbonate calcium waters are common; in the western regions of the forest-steppe zone, fresh calcareous calcium waters, which, with progress to the east, gradually transform into bicarbonate calcium-magnesium-sodium. Near the border of the steppe zone, sulphates begin to play an important role in the composition of river waters. In the steppe zone, sulfate-chloride waters of mixed cationic composition prevail.

The chemical composition of the waters of large rivers (the Dnieper, the Dniester, the Southern Bug, the Seversky Donets) also exhibits hydrochemical zoning, which manifests itself mainly in the increase in the water downstream of the rivers of alkali sulfates and chlorides (Khil'chevskii VK, Khil'chevskii RV, Gorokhovskaya, 1999). However, it is little consistent with the boundaries of physical and geographical zones in comparison with the zoning of the chemical composition of the waters of local runoff (small rivers). In the mountainous regions of the country, the hydrochemical zoning for surface water is practically not traced. The river waters here are fresh, bicarbonate calcium.

Area of the basin of the Vistula river (the Western Bug). The main river of the Vistula basin (the Baltic Sea basin) in Ukraine is the transboundary Western Bug River, which also flows through Poland and Belarus. Surface waters of the Western Bug basin are characterized by a hydrocarbonate calcium composition, which is associated with a significant spread of gypsiferous carbonate rocks in the catchment area. The humid type of climate and the predominance of descending flows in soils cause a low content of dissolved ions in water. The mineralization of the river waters of the basin is on average about 500 mg/l-Table 2 (Zabokrytska, Khilchevsky, Manchenko, 2006).

Table 2.Average concentration of main ions and general mineralization of surface waters within the river basin regions of Ukraine, $\mathrm{mg} / \mathrm{l}$.

\begin{tabular}{|l|c|c|c|c|c|c|c|c|}
\hline \multicolumn{1}{|c|}{ Area of the river basin } & $3^{-}$ & $\mathrm{SO}_{4}^{2-}$ & $\mathrm{Cl}^{-}$ & $\mathrm{Ca}^{2+}$ & $\mathrm{Mg}^{2+}$ & $\mathrm{Na}^{+}$ & $\begin{array}{c}\text { General } \\
\text { minera-liza- } \\
\text { tion }\end{array}$ \\
\hline The Vistula & 300 & 44 & 41 & 97 & 12 & 32 & - & 523 \\
\hline The Danube & 176 & 46 & 28 & 43 & 12 & 37 & 6 & 331 \\
\hline The Dniester & 176 & 46 & 61 & 60 & 13 & 47 & 5 & 405 \\
\hline The Southern Bug & 344 & 82 & 53 & 80 & 29 & 53 & 16 & 653 \\
\hline The Dnieper & 229 & 79 & 45 & 66 & 19 & 45 & 9 & 488 \\
\hline The Don & 304 & 294 & 240 & 153 & 43 & 166 & - & 1,192 \\
\hline Rivers of the Black Sea & 393 & 783 & 398 & 196 & 85 & 396 & - & 2,200 \\
\hline $\begin{array}{l}\text { Rivers of the Azov Sea } \\
\text { Region }\end{array}$ & 333 & 783 & 498 & 296 & 85 & 696 & - & 2,200 \\
\hline Rivers of the Crimea & 250 & 118 & 51 & 80 & 22 & 43 & 16 & 580 \\
\hline
\end{tabular}


For the river waters of the Western Bug basin, an inverse relationship is observed between mineralization and water discharge. It was stated that the lowest absolute values of the river Western Bug mineralization is $412 \mathrm{mg} / \mathrm{l}$ (in the year 1963), and the largest $-604 \mathrm{mg} / \mathrm{l}$ (in the year 1988 ). The maximum values of mineralization of water (over $800 \mathrm{mg} / \mathrm{l}$ ) are fixed in the water of the river Poltva below the place of wastewater discharge in the city of Lviv, and the average annual water mineralization of this river was $570 \mathrm{mg} / \mathrm{l}$. The calculations carried out showed that the river Poltva significantly affects the chemical composition of the water of the Western Bug; it forms $66 \%$ of the ionic runoff of the Western Bug in the Kamianka-Buzkastream point.

Area of the basin of the Danube river. The main tributaries of the Danube in the territory of Ukraine are fragmented: in the Transcarpathian region (Uzh and Tisza rivers) and Bukovina (the Prut river) -transboundary rivers that carry water to the territory of Hungary, Romania and Moldova; in the Odessa region - in fact, the lower reaches of the Danube (Kilian estuary). In the lower reaches of the Danube, water flows in, the composition of which was formed in the territory of many European countries, which are located in its basin (Savitskii, Stets'ko, Osadchiy et al., 1994). The flushing regime of the soils of the basin determines the low mineralization of water, which in the rivers Uzh, Rika, Latorica does not exceed $200 \mathrm{mg} / \mathrm{l}$. In the water of the river Tisza mineralization increases to 250-300 $\mathrm{mg} / \mathrm{l}$, and it reaches the highest values in the water of the rivers Siret, Prut, Cheremosh and the lower part of the Danube - 330-370 mg/l. Information on the average chemical composition of the rivers in the Danube River basin is given in Table. 2.

In the long-term aspect, the change in the mineralization of water has a complex character. In its most general form, it can be argued that there has been a gradual decline in recent years. So, if in 1994 the average mineralization of water in the lower part of the Danube was $405 \mathrm{mg} / \mathrm{l}$, then in 2004 it was 348 g/l (Osadchiy, Nabyvanets, Osadcha et al., 2008). It must be noted that the fluctuation in mineralization coincided with the direction of change in water content. At the same time, seasonal fluctuations in water expenditure and mineralization were natural: an increase in water content led to a decrease in the amount of dissolved salts. The maximum mineralization, as a rule, is observed in winter, and the minimum - during the periods of the highest rise in water levels - in spring or in summer.

In the rivers of the mountain part of the Prut river basin, waters of predominantly hydrocarbonate calcium composition are formed with mineralization in the range of $140-360 \mathrm{mg} / \mathrm{l}$ and a total hardness of $2-4 \mathrm{mmol} / \mathrm{l}$. The rivers of the left-bank part of the Prut river basin are highly mineralized. The mineralization values reach $1.2 \mathrm{~g} / \mathrm{l}$, and the total hardness is $10-12 \mathrm{mmol} / \mathrm{l}$.

For the Prut river itself, in the hydrochemical regime, characteristic features that are expressed in fluctuations in the mineralization of water in the range $150-800 \mathrm{mg} / \mathrm{l}$. In the upper part of the basin, at the closing line near the town of Chernivtsi, during the spring flood, the water mineralization ranges from $200 \mathrm{mg} / \mathrm{l}$ in high water years to $380 \mathrm{mg} / \mathrm{l}$ - in low water. The composition of the ions is dominated by $\mathrm{HCO}_{3}{ }^{-}$and $\mathrm{Ca}^{2+}$. In the dry period, the mineralization values reach $300 \mathrm{mg} / \mathrm{l}$ in high water years, and $430 \mathrm{mg} / \mathrm{l}$ in dry years. In the middle of the river basin the rod mineralization of water increases, reaching in the low water year $420 \mathrm{mg} / \mathrm{l}$, and low water - 560 $\mathrm{mg} / \mathrm{l}$. In the middle part of the Prut river, the hydrochemical regime of the river is largely determined by the influence of highly mineralized sulfate-sodium groundwater on the left-bank part of the basin. This is expressed in an increase in the concentration of sulfate ions to $220 \mathrm{mg} / \mathrm{l}$, sodium and potassium ions to $130 \mathrm{mg} / \mathrm{l}$. The mineralization of water during the spring flood ranges from 390 to $560 \mathrm{mg} / \mathrm{l}$. At low water values, the mineralization values of water vary between $445-860 \mathrm{mg} / \mathrm{l}$. At this time, $\mathrm{HCO}_{3}{ }^{-}$and $\mathrm{Ca}^{2+}$ ions predominate (Osadchiy, Nabyvanets, Osadcha et al., 2008).

Area of the basin of the Dniester river. The Dniester is transboundary river - it flows through the territory of Ukraine and Moldova. The average salinity of river waters in the Dniester Basin is low and ranges from 286 to $481 \mathrm{mg} / \mathrm{l}$ (Table 2). However, within the basin, the mineralization of river water fluctuates significantly - from 100 to $1000 \mathrm{mg} / \mathrm{l}$ and more. The formation of the chemical composition of river waters in the middle part of the Dniester Basin is affected by karst processes (Aksom, Khilchevskyi, 2002).

In general, in the Dniester river basin, a group of rivers of the upper mountainous part (in the Ukrainian Carpathians) and the plains part of the basin can be distinguished by mineralization of water. The least mineralized (the sum of ions up to 200 $\mathrm{mg} / \mathrm{l})$ are the mountain rivers Bystrica, Svicha, Luzhanka. In the waters of the rivers Slavka, Opor, Crow, Stryi, the sum of dissolved salts varies between 200-300 mg/l. From 300 to $400 \mathrm{mg} / \mathrm{l}$, the mineralization of water in Dniester, Seret, Koroptse, Strv'yazh, Zolota Lypa and Hnyla Lypa changes. High water mineralization is distinguished by the water of the Tysmenytsia- about $1000 \mathrm{mg} / \mathrm{l}$.

The mineralization of the Dniester reservoir (volume $3.0 \mathrm{~km}^{3}$ ) does not exceed $450 \mathrm{mg} / \mathrm{l}$, the composition of dissolved salts is hydrocarbonate - 
calcium (Khilchevskyi, Honchar, Zabokrytskaetal, 2013).

Area of the basin of the Southern Bug river. The Southern Bug is the only large river whose basin is completely within the territory of Ukraine. The diversity of soil-geological, climatic and other conditions from north to south determines the corresponding changes in the chemical composition of river waters in the basin of the Southern Bug. Prior to the town of Pervomaisk, mineralization of river waters does not exceed $1 \mathrm{~g} / \mathrm{l}$, the composition of water is hydrocarbonate- calcium. In the tributaries of the Southern Bug, below the town of Pervomaisk, during the low-water period the mineralization of water reaches $1.7 \mathrm{~g} / \mathrm{l}$, they are mixed in composition - hydrocarbonate-sulphate magnesium or sulphate-chloride sodium.

Directly in the Southern Bug river, composition of water varies both along the course of the river in a spatial sense and in a temporal aspect. The lowest mineralization of water is observed in the river during the spring high water. In the upper course of the river during the high water period, the mineralization of water fluctuates between $180-310 \mathrm{mg} / \mathrm{l} \mathrm{de}-$ pending on the water content of the year, hard water is in the range $2.3-2.9 \mathrm{mmol} / \mathrm{l}, \mathrm{HCO}_{3}{ }^{-}, \mathrm{Ca}^{2+}$ dominate in the composition of ions. In the low-water period in this part of the river, the mineralization of water reaches $570 \mathrm{mg} / \mathrm{l}$, and the hardness -up to 6 $\mathrm{mmol} / \mathrm{l}$ (Khilchevskyi, Chunarov, Romas et al., 2009).

In the middle of the river in the period of high water, the mineralization of water varies between $260-450 \mathrm{mg} / \mathrm{l}$, hard water is $2.8-3.8 \mathrm{mmol} / 1, \mathrm{HCO}_{3}{ }^{-}$ and $\mathrm{Ca}^{2+}$ ions predominate. In the low-water period, the mineralization of water reaches $730-800 \mathrm{mg} / \mathrm{l}$, the hard water is $8.4 \mathrm{mmol} / \mathrm{l}$, the ions $\mathrm{HCO}_{3}^{-}, \mathrm{Ca}^{2+}$, $\mathrm{Na}^{+}$and $\mathrm{K}^{+}$predominate in the water.

In the lower reaches during the period of high water, the mineralization of the water varies from 260 to $620 \mathrm{mg} / \mathrm{l}$, the hard water is 2.8 to $6 \mathrm{mmol} / \mathrm{l}$, the ions $\mathrm{HCO}_{3}^{-}$and $\mathrm{Ca}^{2+}$ predominate (Table 2). Increased mineralization of the Southern Bug water occurs as a result of an increase in the concentration of all major ions.

Area of the basin of the Dnieper river. The chemical composition of the river waters of the transboundary basin of the Dnieper (flowing through the territory of Russia, Belarus and Ukraine) is closely related to its natural conditions. The conducted studies show a close feedback between the mineralization of water and its costs. Due to minor fluctuations in mean annual water availability in the Dnieper Basin, the mineralization of water is not subject to significant changes over time, and on average in most of the basin is $450-550 \mathrm{mg} / \mathrm{l}$ (Table 2).
The composition of the main ions in the Dnieper water is also relatively stable, with $\mathrm{Ca}^{2+}$ prevail ing among them $(50-100 \mathrm{mg} / \mathrm{l}$, sometimes up to 200 $\mathrm{mg} / \mathrm{l})$ and $\mathrm{HCO}_{3}{ }^{-}$ions $(240-350 \mathrm{mg} / \mathrm{l}$, sometimes up to $400 \mathrm{mg} / \mathrm{l})$. At the same time, it should be noted that for the river waters of the Dnieper Basin there is a great diversity of both ionic composition and mineralization of the water (Khilchevskyi, Romas I.M., Romas M.I. et al., 2007).

The mineralization of the rivers of the mixed forest zone does not exceed $600 \mathrm{mg} / \mathrm{l}$, the composition of the dissolved salts is hydrocarbonate- calcium. The rivers of the middle part of the basin (forest-steppe zone) are more mineralized - up to 1000 $\mathrm{mg} / \mathrm{l}$.

In the water of the steppe zone rivers (Orel, Ingulets, Samara, Vovcha), the content of dissolved salts can reach 3,000 mg/l and more. The water composition of these rivers varies from bicarbonate calcium to sulfate magnesium and sulfate sodium (Khilchevskyi, Kravchynskyi, Chunarov, 2012; Sherstiyk, Khilchevskyi, 2012).

Water mineralization of the large reservoirs of the Dnieper river (Kievske - volume of $3.7 \mathrm{~km}^{3}$; Kanivske - $2.5 \mathrm{~km}^{3}$; Kremenchukske - $13.5 \mathrm{~km}^{3}$; Kamianske - $2.5 \mathrm{~km}^{3}$; Dniprovske $-3.3 \mathrm{~km}^{3}$; Kakhovske $-18.2 \mathrm{~km}^{3}$ ) does not exceed $500 \mathrm{mg} / \mathrm{l}$, the composition of dissolved salts - bicarbonate calcium (Denisova, Timchenko, Nahshinaetal., 2007).

Area of the basin of the Don river (Seversky Donets).The Seversky Donets is a large river in the east of Ukraine, it flows into the territory of Russia into the river Don. The chemical composition of water in the rivers and reservoirs of the Seversky Donets Basin varies considerably over time, depending on the prevalence of the water in these or other genetic categories in their balance. In most of the territory, the minimum mineralization of river water with the greatest water discharge in rivers varies between 120 and $300 \mathrm{mg} / \mathrm{l}$, and at low floods it reaches 1,000 $\mathrm{mg} / \mathrm{l}$. In the right-bank part of the basin, in catchments to the south of the river Berek, in the middle of the water, sulfate-hydrocarbonate, sulfate-chloride and chloride-sulfate compounds are formed. The mineralization values reach $2,000-5,000 \mathrm{mg} / \mathrm{l}$.

In the Seversky Donets itself, the mineralization of water varies widely. In the upper part of the current, the mineralization usually does not exceed $630 \mathrm{mg} / \mathrm{l}$, the dominant are $\mathrm{HCO}_{3}{ }^{-}$and $\mathrm{Ca}^{2+}$ ions. Downstream, the composition of the water changes. These changes are shown clearly in the city of Lisichansk, where the Right-Bank tributaries - the Kazenyi Torets and Bakhmutka rivers-have significant influence on the composition of the Seversky Donets water. In this area, the mineralization values reach their maximum - up to $1,000-1,600 \mathrm{mg} / \mathrm{l}(\mathrm{Ta}-$ ble 2). The composition of the water is characterized 
by increased concentrations of sulfates (200-300 $\mathrm{mg} / \mathrm{l}$ ) and chlorides - up to $130 \mathrm{mg} / \mathrm{l}$ (Osadchiy, Nabyvanets, Osadcha et al., 2008).

Area of the basin of the Black Sea.The formation of the chemical composition of the water of rivers region during the winter and spring high water largely depends on precipitation, which come in the form of snow or rain, the frequency and the duration and intensity of thaws. According to the data of long-term observations, the mineralization of the waters of the rivers of the Black Sea region varies during these periods from 220 to $680 \mathrm{mg} / \mathrm{l}$ (Table 2), hard water - from 1.8 to $6.5 \mathrm{mmol} / \mathrm{l}$. River waters have bicarbonate calcium-magnesium, more rarely sulfate calcium-magnesium composition.

In dry years in the drainage basin, the mineralization of meltwater can reach $1.2 \mathrm{~g} / \mathrm{l}$, the hard water increases to $10 \mathrm{mmol} / \mathrm{l}$.

During the summer and winter, the mineralization ranges from 1 to $3.2 \mathrm{~g} / \mathrm{l}$, the hardness is 9 to $26 \mathrm{mmol} / \mathrm{l}$. The composition of the water is sulfate sodium-magnesium-calcium.

In the rivers that flow to the east of the river Cogilnic, which flows into the Sasic estuary, the water salinity is higher. Thus, according to long-term observations on the Botna river, the Lunga, the Kirgizh-Kitay - mineralization of the water may reach $10 \mathrm{~g} / \mathrm{l}$, and hard water- $30 \mathrm{mmol} / \mathrm{l}$ or more. The river waters have a sulfate-sodium composition.

The mineralization of the water of the small rivers that flow between the rivers Dniester-Southern Bug (Kuchurhan, Maly and Velykyi Kuyalnik, Tylihul) is 1.3 to $3 \mathrm{~g} / \mathrm{l}$, hard water is 10 to $27 \mathrm{mmol} / \mathrm{l}$. The water has a chloride sodium-magnesium composition (Gorjev, Peleshenko, Khilchevskyi, 1995).

Area of the basin of the Azov Sea.The chemical composition of the water of rivers flowing into the Azov Sea is formed in conditions of arid climate, which predetermines their high mineralization. The range of fluctuations of average annual mineralization indicators is quite wide $-1,000-2,500 \mathrm{mg} / \mathrm{l}$ (Table 2), with absolute $590-26,000 \mathrm{mg} / \mathrm{l}$. It should be noted that the minimum values of mineralization of water are characteristic only for the period of flood, when waters of mixed hydrocarbonate-sulfate calcium composition with mineralization of $590-700$ $\mathrm{mg} / \mathrm{l}$ are formed.

In the north-eastern part of the region, in the upper reaches of the rivers Mius, Kalmius and Mokriy Yelanchik, the channel waters have a sulphate-sodium composition with a mineralization of $1,500-2,000 \mathrm{mg} / \mathrm{l}$ and a hardness of 11-20 mmol/l.

In the southern part, in the middle and lower currents of Kalmius, Mius and Mokriy Yalanchik, in the rivers Kalchik, Berda and Obytichna, as well as in the upper and middle currents of the Molochna, the mineralization of channel water varies in the range 2,000-4,000 mg/l, hardness $15-30 \mathrm{mmol} / \mathrm{l}$, the water has a sulfate calcium-sodium composition.

In the southwestern part of the region, in the Lozuvatka and the Korsak rivers, as well as in the lower reaches of the Molochna, the mineralization of channel water reaches $6,000 \mathrm{mg} / \mathrm{l}$, and the hardness is $25-60 \mathrm{mmol} / \mathrm{l}$.

The mineralization of the water of the rivers of the Syvash area, which dry up (to the west of the Molochna River), reaches 15-26 g/l during the summer low; by ionic composition, these waters have sulfate-chloride sodium or chloride sodium composition (Gorjev, Peleshenko, Khilchevskyi, 1995).

Area of the basin of the Crimea rivers. The amount of atmospheric precipitation and its distribution throughout the year, as well as the peculiarities of the temperature regime, predetermine the flooding character of the hydrological regime of the Crimean rivers, as does the copious washing of readily soluble salts from the soils of the mountainous part of the catchments from. The mineralization of the channel water in the mountain part during the winter-spring period and during showers is $200-300 \mathrm{mg} / \mathrm{l}$ on the southern and western slopes, $250-350 \mathrm{mg} / \mathrm{l}$ in the northern and $250-500 \mathrm{mg} / \mathrm{l}$ on the northeastern slopes of the mountains. The water has a hydrocarbonate calcium composition.

In the low-water period (June-October), the mineralization of channel water in the mountainous part of the rivers is $450-550 \mathrm{mg} / \mathrm{l}$ on the western slopes, $450-650 \mathrm{mg} / \mathrm{l}$ in the northern, $450-850 \mathrm{mg} / \mathrm{l}$ in the southern and $550-750 \mathrm{mg} / \mathrm{l}-$ on the northeastern slopes of the mountains. The water has a hydrocarbonate calcium composition.

The mineralization of channel water in the winter (December-March) is $200-300 \mathrm{mg} / \mathrm{l}$ on the western slopes and 350-700 $\mathrm{mg} / \mathrm{l}$ on the northern and eastern slopes. The waters have a hydrocarbonate- calcium and hydrocarbonate-sulphate calcium composition.

In the transition to the steppe part of the Crimea, the following is noted. In the summer-autumn period, mineralization of channel water significantly increases and reaches $750-1000 \mathrm{mg} / \mathrm{l}$ below the western slopes, $1,000-1,750 \mathrm{mg} / \mathrm{l}$ - below the northern and 1000-4000 mg/ - below the eastern slopes of the Crimean Mountains. The waters have the following composition: hydrocarbonate-sulphate calcium-magnesium and sulphate-hydrocarbonate calcium-magnesium; sulfate calcium-magnesium; chloride-sulphate sodium or chloride-sodium.

If during the flood period, mainly from January to February and during downpours, the mineralization of the water of melted snow and rainwater in the gullies and ponds of the Steppe Crimea is 160$700 \mathrm{mg} / \mathrm{l}$, then during the low-water period (from March to November) the water mineralization 
reaches 7,500-28,000 $\mathrm{mg} / \mathrm{l}$ and it becomes chloridesulfate or chloride.

Modern evaluation of the anthropogenic component contribution shows that approximately 10$20 \%$ of the runoff of dissolved mineral substances with river waters is formed due to economic activity (Zakrevskii, Peleshenko, Khil'chevskii, 1988).

Lakes. In Ukraine, there are about 20 thousand lakes, among which 7 thousand have a surface area of more than $0.1 \mathrm{~km}^{2}$. The most famous are the fresh Shatsky Lakes, among which is Svityaz - the deepest lake in Ukraine $(58.6 \mathrm{~m})$, fresh-semi-saline Danube lakes, among which is Yalpuh - the largest lake in Ukraine $\left(149 \mathrm{~km}^{2}\right)$, the salt lakes of the Crimea. The mineralization of lake water, unlike rivers, varies widely. There are lakes with very fresh water and mineralization, as in atmospheric precipitation (for example, Maricheyka - a small lake of glacial origin in the Ukrainian Carpathians - $30 \mathrm{mg} / \mathrm{l}$ ) and those whose salt concentration is a brine with a salinity of more than $100 \mathrm{~g} / \mathrm{l}$ (salt lake of the Crimea).

Shatsky lakes. The significant amount of precipitation in the Shatsky lakes region (the basin of the Western Bug River, the Volyn Region) contributes to good soil washing and the relative poverty of the surface waters that feed the lakes with mineral compounds. Table 3 shows the chemical composition of the water of some lakes of the Shatsky group (Khilchevskyi, Osadchiy, Kurylo, 2012). As you can see, the water in these lakes is very fresh -132.2 $198.7 \mathrm{mg} / \mathrm{l}$, and the hard water is $1.3-1.7 \mathrm{mmol} / \mathrm{l}$.

Table 3. Average concentration of main ions and general mineralization of water in Shatsky lakes, mg/l

Table 3. Average concentration of main ions and general mineralization of water in Shatsky lakes, mg/l
\begin{tabular}{|c|c|c|c|c|c|c|c|}
\hline Lakes & $3^{-}$ & $\mathrm{SO}_{4}^{2-}$ & $\mathrm{I}^{-}$ & & $\mathrm{g}^{2+}$ & $\mathrm{N}^{+}+{ }^{+}$ & General mineralization \\
\hline Svityaz & 122.1 & 10.2 & 13.7 & 34.1 & 3.7 & 15.0 & 198.7 \\
\hline Peremut & 85.4 & 3.2 & 11.6 & 20.1 & 3.7 & 12.5 & 136.5 \\
\hline Pisochne & 84.1 & 3.1 & 10.9 & 18.8 & 3.1 & 12.2 & 132.2 \\
\hline
\end{tabular}

Danube Lakes.The mineralization of Danube floodplain lakes (Odessa region) is largely predetermined by their water exchange with the Danube. In the lakes located downstream of the Danube and less associated with it, the water salinity is higher than in the lakes located upstream of the river. The mineralization of lake water is also affected by groundwater, as a result of which the bottom layers of water are usually more mineralized than surface water.

During the inflow of the Danube waters to the lakes Cahul, Kuhurluy, Yalpug, Sofyan and Katlabukh, the mineralization of their waters reaches the minimum values $(225-390 \mathrm{mg} / \mathrm{l})$, and the total hardness is $2.9-3.8 \mathrm{mmol} / \mathrm{l}$. The composition of water is calcium bicarbonate.

In the Lake Kitay, where communication with the Danube is difficult, the lowest mineralization is $1.15 \mathrm{~g} / \mathrm{l}$, and the total hardness is $8.1 \mathrm{mmol} / \mathrm{l}$. The composition of the ions is dominated by sulfates, chlorides and sodium.

In winter, the water salinity in Cahul, Kuhurluy, Yalpug, Sofyan and Katlabukh ranges from 0.5$1.5 \mathrm{~g} / \mathrm{l}$, and the total hardness is $5-13 \mathrm{mmol} / \mathrm{l}$. In addition, the water composition in Cahul and Kuhurluy is hydrocarbonate- calcium, and in Yalpug, Sofyan and Katlabukh-sulfate sodium.

In Lake Kitay, the mineralization of the water in winter is $2.5 \mathrm{~g} / \mathrm{l}$, the total hardness is $13-14$ $\mathrm{mmol} / \mathrm{l}$, the predominant ions are $\mathrm{SO}_{4}{ }^{2-}, \mathrm{Cl}^{-}, \mathrm{Na}^{+}$.

Table 4 shows average concentrations of the main ions and mineralization in the water of the Danubian lakes (Gorjev, Peleshenko, Khilchevskyi, 1995).

Salt Lakes of the Crimea. In the Crimea, there are over 50 salt lakes, which are sources of salt and balneological mud. The high temperature of the air and brine, and low air humidity lead to intensive evaporation of water and increase of concentration of brines in salt lakes.

By location, the salt lakes of the Crimea are divided into groups: Perekopska, Tarkhankutska, Evpatoriska, Khersoneska, Kerchenska, Prisivashska. The lowest level of mineralization is of the lakes of the Perekopska group - 200-250 g/l (Lake Aigulske, Kirleutske, etc.). The smallest mineralization is found in the lacustrine lakes of the Tarkhankutska group, 55-110 g/l (Lake Bakalske, Dzharylhach, etc.).

Table 4. Average concentration of main ions and general mineralization of water in the Danube lakes, $\mathrm{mg} / \mathrm{l}$

\begin{tabular}{|c|c|c|c|c|c|c|c|}
\hline Lakes & $3^{-}$ & $\mathrm{SO}_{4}{ }^{-}$ & $\mathrm{l}^{-}$ & ${ }^{2+}$ & $\mathrm{g}^{2+}$ & $\mathrm{N}^{+}+$ & $\begin{array}{c}\text { General mineraliza- } \\
\text { tion }\end{array}$ \\
\hline Yalpug & 224 & 433 & 221 & 62.8 & 69.8 & 272 & 1,316 \\
\hline Kugurluy & 188 & 351 & 155 & 46.1 & 39.5 & 230 & 1,012 \\
\hline Katlabuh & 195 & 388 & 165 & 76.1 & 67.5 & 164 & 1,056 \\
\hline Kitay & 150 & 445 & 209 & 65.5 & 77.0 & 227 & 1,236 \\
\hline Sofiyan & 348 & 462 & 252 & 77.7 & 100 & 215 & 1,374 \\
\hline Kagul & 191 & 95.0 & 59.5 & 46.8 & 23.4 & 53.6 & 460 \\
\hline
\end{tabular}


Anthropogenic influence on the formation of the hydrochemical regime of lakes occurs as a result of changes in the intensity of water exchange with surrounding water bodies and due to the receipt of pollutants with atmospheric precipitation. A positive example of protection of lakes is the fact that the Shatsky lakes in Volhyn region became part of the Shatsky National Nature Park, established in Ukraine in 1983.

Groundwaters. Within Ukraine, seven hydrogeological regions of the first order are distinguished: the folded hydrogeological region of the Ukrainian Carpathians; Volyn-Podilsky artesian basin; hydrogeological area of the Ukrainian Shield; The Dnieper-Donetsk Artesian Basin; Donetsk folded hydrogeological region; Black Sea artesian basin; (Kamzist, Shevchenko, 2009). In the chemical composition of groundwater in different structural regions, both latitudinal and vertical (deep) zoning is observed.

The vertical (deep) hydrochemical zoning is manifested in the isolation of zones of intensive and difficult water exchange in the section of the sedimentary stratum.

1) Zone of intensive water exchange. Usually it is located at depths from $100 \mathrm{~m}$ to $1,000 \mathrm{~m}$ from the day surface. In this zone, the components of the mineral composition of groundwater arrive in small amounts together with atmospheric precipitation, which are filtered; further increase in mineralization and change in their chemical composition occurs as a result of leaching of readily soluble compounds from rocks, especially from Quaternary deposits (gypsum plasters), ion exchange and diffusion transition of pore solutions from clayey waterproof layers. Hydrocarbonate waters with mineralization up to $1 \mathrm{~g} / \mathrm{l}$ dominate, suitable for drinking water supply, sometimes mineralization can reach $3 \mathrm{~g} / \mathrm{l}$.

2) Highly mineralized (50-300 g/l and more) chloride sodium and chloride sodium-calcium waters are distributed in the zone of hindered water exchange. It can be assumed that in this zone there are complex-metamorphosed and highly mineralized waters of old seas (Kamzist, Shevchenko, 2009). Such brines are usually found at great depths of $2 \mathrm{~km}$ (Table 5).

In some aquifers, heterogeneity of the chemical composition of waters is also observed. This is predetermined by the peculiarities of the geological structure of individual territories. Thus, for aquifers of Neogene sediments that belong to the zone of active water exchange, a low mineralization and a hydrocarbonate-calcium composition of water are characteristic. But in the interfluves of the DanubeDnieper in the Neogene sediments an aquifer occurs in sediments of the Kuyalnik age with mineralization up to $300 \mathrm{~g} / \mathrm{l}$ and chloride-sodium composition.

The aquifer of the Jurassic deposits is characterized almost everywhere by mineralization up to 1 $\mathrm{g} / \mathrm{l}$ and by hydrocarbonate-calcium or sodium composition, it is widely used for local household and drinking water supply. But within the Precarpathian trough or in the region of the thermal waters of the shale deposits of the Crimea, the mineralization of the waters of the Jurassic horizon increases to 100 $300 \mathrm{~g} / \mathrm{l}$, the ion composition changes to sodium chloride.

The latitudinal hydrochemical zoning is observed mainly in the aquifers of Quaternary sediments and is manifested in the regular change of waters with mineralization from $0.2-1 \mathrm{~g} / \mathrm{l}$ with a hydrocarbonate- calcium composition in the north-west to waters with mineralization up to $2-15 \mathrm{~g} / \mathrm{l}$ and chloride-sodium composition in the south-east of the country.

Seas. The Black and Azov Seas, which belong to the basin of the Atlantic Ocean, wash the southern part of Ukraine for almost 2 thousand $\mathrm{km}$, the total water surface area of these seas is 461,000 $\mathrm{km}^{2}$.

The Black Sea. The main ionic composition of the Black Sea water has all the characteristic features of ocean waters, but differs from them in relative poverty in ions of chlorine and sodium. The large river runoff and the flow of saline waters from the Marmara Sea determine the average salinity of the Black Sea-18-19\%o (Table 6). In general, salinity on its surface is almost 2 times less than salinity of surface waters of the seas of the World Ocean $(34.5 \%$ o). A relatively stable chlorine balance of the Black Sea was established, which is explained by the intake of salts with the Lower Bosporus Current and the river runoff and their removal by the Upper Bosporus Current.

The distribution of salinity on the sea surface is characterized by a slight increase (from 17.5 to $18.3 \%$ ) from the northwest to the southeast. This is due to the already mentioned influence of the rivers that flow into the northwestern part of the Black Sea. A decrease in the salinity of waters (up to 5-10\%) is also observed in a narrow coastal belt near the mouths of large rivers (Danube, Dniester, Southern Bug, Dnieper). The slight desalination of the Black Sea waters near the Kerch Strait is explained by the penetration here of the less saline waters of the Azov Sea. In summer, a significant amount of river flow supports the desalination of the sea, and the sea currents spread this phenomenon to the east and to the south-western coast of the Crimea. 
Table 5. Characteristics of the chemical composition of groundwater most common aquifers and complexes on the territory of Ukraine

\begin{tabular}{|c|c|c|c|c|}
\hline Era & System & $\begin{array}{c}\text { General mineralization, } \\
\mathrm{mg} / \mathrm{l}\end{array}$ & Total hardness, mmol/1 & $\begin{array}{c}\text { Prevailing ions } \\
\text { (according to O.A. Alekin) }\end{array}$ \\
\hline \multirow{3}{*}{ 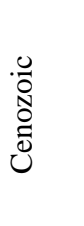 } & Quaternary & $100-15,000$ & $5-30$ & $\mathrm{C}^{\mathrm{Ca}} \mathrm{S}^{\mathrm{Na}}, \mathrm{Cl}^{\mathrm{N}}$ \\
\hline & Neogene & $\begin{array}{c}500-5,500 ; \\
\text { Precarpathian deflection-to } \\
30,0000 \\
\end{array}$ & $4-30$ & $\mathrm{C}^{\mathrm{Ca}}, \mathrm{C}^{\mathrm{Na}}, \mathrm{S}^{\mathrm{C}}, \mathrm{S}^{\mathrm{Na}}, \mathrm{Cl}^{\mathrm{N}}$ \\
\hline & Paleogene & $500-11,500$ & $2-13$ & $\mathrm{C}^{\mathrm{Ca}}, \mathrm{S}^{\mathrm{Na}}, \mathrm{S}^{\mathrm{C}}, \mathrm{S}^{\mathrm{Na}}, \mathrm{Cl}^{\mathrm{N}}$ \\
\hline \multirow{8}{*}{$\begin{array}{l}.0 \\
0 \\
0 \\
0_{0}^{0} \\
\sum_{i}^{0}\end{array}$} & Cretaceous & $\begin{array}{l}\quad 400-2,000 \\
\text { rarely to } 50,000\end{array}$ & $2-15$ & $\mathrm{C}^{\mathrm{Ca}}, \mathrm{S}^{\mathrm{Na}}, \mathrm{Cl}$ \\
\hline & Jurassic & $\begin{array}{l}500-3,000 ; \text { Precarpathian de- } \\
\text { flection, thermal waters of the } \\
\text { shale deposits of the Crimea - } \\
\text { up to } 10,0000\end{array}$ & $3-15$ & $\mathrm{C}^{\mathrm{Ca}}, \mathrm{S}^{\mathrm{Ca}}, \mathrm{S}^{\mathrm{Na}}, \mathrm{CI}$ \\
\hline & Triassic & $\begin{array}{c}600-5,000 \\
\text { rarely up to } 50,000\end{array}$ & $4-20$ & $\mathrm{C}^{\mathrm{Ca}}, \mathrm{S}^{\mathrm{Na}}, \mathrm{Cl}^{\mathrm{Na}}$ \\
\hline & Permian & $\begin{array}{c}1,200-7,000 \\
\text { up to300,000 in salt deposits }\end{array}$ & $>15$ & $\mathrm{~S}^{\mathrm{Ca}}, \mathrm{Cl}^{\mathrm{Na}}$ \\
\hline & Carbon & $1,200-7,000$ & $>10$ & $\mathrm{~S}^{\mathrm{Ca}}, \mathrm{S}^{\mathrm{Na},} \mathrm{Cl} \quad, \mathrm{Cl}^{\mathrm{Na}}$ \\
\hline & Devon & $900-7,000$ & $7-15$ & $\mathrm{~S}^{\mathrm{Ca}}, \mathrm{S}^{\mathrm{Na}}, \mathrm{Cl}^{\mathrm{Na}}$ \\
\hline & $\begin{array}{l}\text { Silurian-Ordovi- } \\
\text { cian } \\
\end{array}$ & $\begin{array}{l}\text { preferably } 500-1,000 ; \text { some- } \\
\text { times too } 3,000-50,000\end{array}$ & $4-30$ & $\mathrm{C}^{\mathrm{Ca}}, \mathrm{C}^{\mathrm{Na}}, \mathrm{Cl}^{\mathrm{Na}}$ \\
\hline & Cambrian & 65,000 & 30 & $\mathrm{Cl}^{\mathrm{Na}}$ \\
\hline 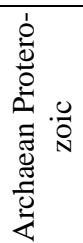 & Precambrian & $1,000-300,000$ & $6-30$ & $\mathrm{~S}^{\mathrm{Ca}}, \mathrm{S}^{\mathrm{Na}}, \mathrm{Cl}^{\mathrm{Na}}$ \\
\hline
\end{tabular}

The salinity of the Black Sea water increases with depth in the open sea, from 17-18\%o on the surface to $22.5 \%$ near the bottom. A feature of the distribution of salinity along the vertical is the existence of a permanent halocline between the horizons. At a depth of 100-150 m, salinity increases from 18.5 to $21 \%$. The significant variety of the salinity at different horizons of depths is explained by: the freshening effect of river flow; the entry into the deep layers of the Marmara Sea saline waters (34$35 \%$ ); features of the general circulation of the Black Sea. Seasonal changes in salinity are observed up to a depth of $150 \mathrm{~m}$ in the western part of the sea and up to $100-120 \mathrm{~m}$ in the eastern, deeper salinity is the same throughout the sea (Skopintsev, 1975).

A characteristic feature of the Black Sea is that its waters at depths of 100-200 m are devoid of oxygen, which is replaced by hydrogen sulfide. And in the hydrogen sulfide environment, only anaerobic bacteria live. Hydrogen sulfide occupies $87 \%$ of the Black Sea. In connection with anthropogenic pollution of the sea, the hydrogen sulfide zone approaches the sea surface.

Table 6.Average values of salinity and content of the main ions in the waters of the Black and Azov Seas, as well as the ocean, \%o

\begin{tabular}{|c|c|c|c|c|c|c|c|}
\hline $\mathrm{Na}^{+}$ & $\mathrm{K}^{+}$ & $\mathrm{Mg}^{2+}$ & $\mathrm{Ca}^{2+}$ & $\mathrm{Cl}^{-}$ & $\mathrm{SO}_{4}{ }^{2-}$ & $3^{-}$ & Salinity \\
\hline \multicolumn{8}{|c|}{ The Black Sea } \\
\hline 5.795 & - & 0.697 & 0.253 & 10.23 & 1.441 & 0.198 & 18.614 \\
\hline \multicolumn{8}{|c|}{ The Azov Sea } \\
\hline 5.795 & 0.132 & 0.428 & 0.172 & 6.538 & 0.929 & 0.169 & 11.885 \\
\hline \multicolumn{8}{|c|}{ The Sivash } \\
\hline 6.26 & - & 0.77 & 0.31 & 11.13 & 1.65 & 0.21 & 20.33 \\
\hline \multicolumn{8}{|c|}{ Ocean } \\
\hline 10.56 & 0.38 & 1.27 & 0.41 & 18.98 & 2.65 & 0.14 & 34.45 \\
\hline
\end{tabular}


The Azov Sea.The main ionic composition of the water of the open part of the Azov Sea possesses all the characteristic features of the ocean waters, but differs from them in relative poverty with ions of chlorine and sodium and in the increased content of the predominant ions of surface waters of sushi, calcium, hydrocarbonates and sulfates.

The similarity and difference in the composition of the waters of the Azov Sea from the ocean and Black Sea waters is a consequence of the fact that the Azov water is formed as a result of the gradual mixing first of the ocean waters with the Black Sea and then the Black Sea waters with the waters of the rivers that flow into the Azov Sea.

In the Azov Sea, four regions are distinguished, in which a peculiar mode of the main ions can be observed: the pre-piercing - part of the sea near the Kerch Strait; the Sivash Area; Taganrog Bay; the mouth of the river Kuban.

In winter, the salinity of the water is high in the Azov Sea. The low inflow from rivers, the low sea level predetermines an increased influx of Black Sea waters, ice formation and all together - increased salinity of the sea water. Sometimes water with a salinity of $12 \%$ reaches Taganrog Bay, and in the pre-piercing part of the Kerch Strait near the bottom the salinity can reach $14.47 \%$.

In the spring, salinity of the Azov water begins to be seriously affected by an increase in river flow into the sea, melting snow, changing the general hydro-meteorological conditions. Throughout the water area of the sea, salinity in the spring is about $11 \%$, at the entrance to Taganrog Bay -10 $\%$. Fresh water near the mouth of the river Don is not stable, and Don water can spread far into Taganrog Bay, or press close to the mouth of the river (salinity varies from 4.21 to $11.45 \%$ ), depending on the amount of river flow.

In the summer until July, the salinity of water continues to decrease due to the freshening effect of river flow. At the entrance to Taganrog Bay salinity ranges from 8.12 to $10.4 \%$. In the central part of the sea salinity is $11-11.5 \%$.

In the autumn in the Azov Sea, the salinity of the water rises and reaches the highest level - up to $13 \%$ in the central and western parts of the high sea.

Many years of changes in the salinity of the Azov Sea are of interest. Thus, for the period 19231951 it was $10.9 \%$ o, for the years 1952-1970- increased to $11.8 \%$ and up to the $90 \mathrm{~s}$ it reached $13.8 \%$. Such a significant increase in salinity over a relatively short period of time is associated with anthropogenic reduction in river flow, which in recent years has coincided with a depression in the moisture content of the whole catchment area due to climatic changes. The sea is largely affected by hydrological, hydrochemical and biological processes taking place in it.

\section{Conclusions:}

1. The chemical composition of Ukraine's natural waters (rivers, lakes, underground aquifers, seas) is the result of the interaction of a combination of physiographic and geological factors, as well as their location, mainly in the temperate climatic zone.

2. The average long-term general mineralization of atmospheric precipitation feeding water bodies is usually low - within the limits of $20-40 \mathrm{mg} / \mathrm{l}$, its chemical composition is predominantly sulfate, magnesium-calcium,the magnitude of the anthropogenic component in the composition of atmospheric precipitation reaches $70-75 \%$.

3 . For the chemical composition of small and medium-sized rivers of Ukraine, there is a certain hydrochemical zoning in the direction from the northwest of the south-east of the country. In the same direction, general mineralization of river waters also increases (from 200-300 mg/l to 1,500-3,000 mg/l and more). Hydrochemical zoning, in general, is consistent with the limits of physical and geographical zones. Accordingly, the composition of waters varies from hydrocarbonate- calcium in the north and west to sodium chloride in the south and southeast. The mineralization values of the water of large rivers (the Danube, the Dnieper, the Desna, the Pripyat, the Dniester, and the Southern Bug) in Ukraine do not exceed $600 \mathrm{mg} / \mathrm{l}$ (except the river Seversky Donets). The magnitude of the anthropogenic component of the ion flow of rivers reaches $10-20 \%$.

4. The mineralization of lakes water, unlike rivers, varies widely. There are lakes with very fresh water and general mineralization, as in atmospheric precipitation $(30 \mathrm{mg} / \mathrm{l}-$ small lakes of glacial origin in the Ukrainian Carpathians), and those whose salt concentration is brine with a mineralization of more than $100 \mathrm{~g} / \mathrm{l}$ (salt lakes of the Crimea). The most famous groups of lakes are the Shatsky with water general mineralization of $132.2-198.7 \mathrm{mg} / \mathrm{l}$, the Danube $(0.5-1.4 \mathrm{~g} / \mathrm{l})$, the salt lakes of the Crimea $(55-255$ $\mathrm{g} / \mathrm{l})$. Anthropogenic influence on the formation of the hydrochemical regime of lakes occurs as a result of changes in the intensity of water exchange with surrounding water bodies and due to the receipt of pollutants with atmospheric precipitation.

5 . In the chemical composition of groundwater in different structural regions, in the majority of cases vertical hydrochemical zoning appears in the territory of Ukraine, which manifests itself in the isolation of zones of intensive or difficult water exchange in the section of the sedimentary stratum. The active water exchange zone is characterized by hydrocarbonate or sulfate waters with a small mineral content 
(up to $1.0 \mathrm{~g} / \mathrm{l}$ ), suitable for water supply. Highly mineralized (50-300 g/l and more) chloride sodium and chloride sodium-calcium waters are distributed in the zone of hindered water exchange. Anthropogenic influence on the formation of the chemical composition of groundwater is insignificant.

6. The basic ionic composition of the Black Sea water has all the characteristic features of ocean waters, but differs from them in relative poverty in ions of chlorine and sodium. The large volume of river flow and water exchange with the Marmara Sea predetermine the average salinity of the Black Sea at the level of 18-19\%o, which is almost half the salinity of the World Ocean $(34.5 \%$ o). Decrease in the salinity of the Black Sea waters (up to 5-10\%o) is observed in the narrow coastal zone near the large river mouths (the Danube, the Dniester, the Southern Bug, and the Dnieper).

The main factors that determine the salinity regime in the Azov Sea (10-13\%o) are the inflow of saline Black Sea and fresh river (the Don and the Kuban rivers) waters that are mixed in the Azov Sea, as well as the arrival of atmospheric precipitation.

\section{References}

Aksom S.D., Khilchevskyi V.K., 2002. Vplyv sulfetnoho karstu na khimichnyi sklad pryrodnykh vod u baseini Dnistra [Influence of sulfate karst on the chemical composition of natural waters in the Dniester basin]. Nika-Tsentr, Kyiv (in Ukrainian). Almazov A.M., 1962. Gidrohimiya ustevyih oblastey rek [Hydrochemistry of estuarine river areas]. AN USSR, Kiev (in Russian).

Babinets A.E., Belyavskiy G.A., 1973. Estestvennyie resursyi podzemnyih vod zonyi intensivnogo vodoobmena Ukrainyi (na osnove analiza podzemnogo stoka) [Natural resources of groundwater in the zone of intensive water exchange of Ukraine (based on analysis of underground runoff)]. Naukova dumka, Kiev (in Russian).

Babinets A. E., Borevskiy B. V., Shestopalov V. M. i dr., 1979. Formirovanie ekspluetetsionnyih resursov podzemnyih vod pletformennyih struktur Ukrainyi [Formation of operational resources of underground waters of platform structures of Ukraine]. Naukova dumka, Kiev (in Russian).

Denisova A.I., Timchenko V.M., Nahshina E.P. i dr., 1989. Gidrologiya i gidrohimiya Dnepra i ego vodohranilisch [Hydrology and hydrochemistry of the Dnieper and its reservoirs]. Naukova dumka, Kiev (in Russian).

Directive 2000/60/EC of the European Parliament and of the Council establishing a framework for the Community action in the field of weter policy. Retrieved from http://ec.europa.eu/environment/weter/weter-framework/index_en.html.

Eremeeva L.V., Eremeev V.N., Bezborodov A.A., 1984. Issledovanie migretsii mikroelementov zhelezomargantsevoy gruppyi $\mathrm{v}$ vode $\mathrm{i}$ osadkah glubokovodnoy chasti Chernogo morya. V kn.: Kompleksnyie issledovaniya Chernogo morya. [Study of the migration of trace elements in the iron-manganese group in the water and sediments of the deep-water part of the Black Sea. In the book: Comprehensive Research of the Black Sea]. Sevastopol (in Russian).

Gorev L.N., Peleshenko V.I., 1991. Osnovyi melioretivnoy gidrohimii [Fundamentals of meliorative hydrochemistry]. Vyischa shkola, Kiev (in Russian).

Horiev L.M., Peleshenko V.I., Khilchevskyi V.K., 1995. Hidrokhimiia Ukrainy [Hydrochemistry of Ukraine]. Vyshcha shkola, Kyiv (in Ukrainian).

Kamzist Zh. S., Shevchenko O. L., 2009. Hidroheolohiia Ukrainy [Hydrogeology of Ukraine]. Firma «INKOS», Kyiv (in Ukrainian).

Khilchevskyi V.K., 1996. Rol ahrokhimichnykh zasobiv u formuvanni yakosti vod baseinu Dnipra [The role of agrochemicals in shaping the water quality of the Dnipro basin]. VPTs «Kyivskyi universytet», Kyiv (in Ukrainian).

Khilchevskyi V.K., Chunarov O.V., Romas M.I., Yetsiuk M.V., 2009. Vodni resursy ta yakist richkovykh vod baseinu Pivdennoho Buhu [Water resources and quality of river basins of the Southern Bug]. Nika-Tsentr, Kyiv (in Ukrainian).

Khilchevskyi V.K., Honchar O.M., Zabokrytska M.R., Stashuk V.A., Chunarov O.V., 2013. Hidrokhimichnyi rezhym ta yakist poverkhnevykh vod baseinu Dnistra na terytorii Ukrainy [Hydrochemical regime and quality of surface waters of the Dniester basin in the territory of Ukraine]. Nika-tsentr, Kyiv (in Ukrainian).

Khilchevskyi V. K., Hrebin V.V., 2017. Hidrohrafichne ta vodohospodarske raionuvannia terytorii Ukrainy, zetverdzhene u 2016 r. - realizetsiia polozhen VRD S [Hydrographic and water-management zoning of the territory of Ukraine, approved in 2016 - Implementation of the provisions of the EU WFD]. Hidrolohiia, hidrokhimiia i hidroekolohiia. 1(44), 8-20.(in Ukrainian).

Khilchevskyi V.K., Kravchynskyi R.L., Chunarov O.V., 2012. Hidrokhimichnyi rezhym ta yakist vody Inhultsia v umovakh tekhnohenezu [Hydrochemistry and water quality of Ingulets in the conditions of technogenesis]. Nika-Tsentr, Kyiv (in Ukrainian).

Khilchevskyi V. K., Kurylo S.M., 2016. Khimichnyi sklad etmosfernykh opadiv na terytorii Ukrainy ta yoho antropohenna skladova [Chemical composition of atmospheric precipitation in Ukraine and its anthropogenic component]. Hidrolohiia, hidrokhimiia i hidroekolohiia. 4(43), 63-74. (in Ukrainian).

Khilchevskyi V.K., Osadchyi V.I., Kurylo S.M. 2012. Osnovy hidrokhimii [Basics of hydrochemistry]. Nika-tsentr, Kyiv (in Ukrainian).

Khilchevskyi V.K., Romas I.M., Romas M.I. ta in., 2007. Hidroloho-hidrokhimichna kharakterystyka minimalnoho stoku richok baseinu Dnipra [Hydro-hydrochemical characteristic of the minimum runoff 
of the Dnipro River basins]. Nika-Tsentr, Kyiv (in Ukrainian).

Khil'chevskiy V.K., 1994. Effect of agricultural production on the chemistry of natural waters: a survey. Hydrobiological Journal. 30(1), 82-93.

Khil'chevskii V.K., Chebot'ko K.A., 1994. Evaluation of the ecological and hydrochemical state of natural waters in Ukraine. Water Resources. 21(2), 166172.

Khil'chevskii V.K., Khil'chevskii R.V., Gorokhovskaya M.S., 1999. Environmental aspects of chemical substance discharge with river flow into water bodies of the Dnieper River basin. Water Resources. 26(4), 453-458.

Kosovets-Skavronska O.O., Snizhko S.I., 2008. Chasova transformetsiia khimichnoho skladu etmosfernykh opadiv na terytorii Ukrainy [Time transformation of the chemical composition of atmospheric precipitation in Ukraine]. Ekonomichna ta sotsialna heohrafiia. 58, 242-252 (in Ukrainian).

Linnik P.N., Nabivanets B.I., 1986. Formyi migretsii metallov v presnyih poverhnostnyih vodah [Forms of migration of metals in fresh surface waters]. Gidrometeoizdat, Leningrad (in Russian).

Mitropolskiy A.Yu., Bezborodov A.A., Ovsyanyiy E.I., 1982. Geohimiya Chernogo morya [Geochemistry of the Black Sea]. Naukova dumka, Kiev (in Russian).

Ohnianyk M. S., 2000. Mineralni vody Ukrainy [Mineral waters of Ukraine]. Kyivskyi universytet, Kyiv (in Ukrainian).

Osadchyi V.I., Nabyvanets B.I., Osadcha N.M., Nabyvanets Yu.B., 2008. Hidrokhimichnyi dovidnyk [Hydrochemical Directory]. Nika-Tsentr, Kyiv (in Ukrainian).

Osadchyy V., Nabyvanets B., Linnik P., Osadcha N., Nabyvanets Y., 2016. Processes Determining Surface Water Chemistry. Springer.

Peleshenko V.I. 1975. Otsenka vzaimosvyazi himicheskogo sostava razlichnyih tipov prirodnyih vod (na primere ravninnoy chasti Ukrainyi) [Assessment of the relationship between the chemical composition of various types of natural water (for example, the plains of Ukraine)]. Vyischa shkola, Kiev (in Russian).

Peleshenko V.I., Zakrevskiy D.V., Gorev L.N., Romas' N.I., Khil'chevskiy W.K., 1989. Hydrochemical problems in developing natural resources in the Ukrainian SSR. Izvestiya Vsesoyuznogo Geograficheskogo Obshchestva. 121(3), 244-249.

Romas M.I., 2002. Hidrokhimiia vodnykh obiektiv etomnoi i teplovoi enerhetyky [Hydrochemistry of water objects of nuclear and thermal energy]. VPTs «Kyivskyi universytet», Kyiv (in Ukrainian).

Romas N.I., 1979. O formirovanii himicheskogo sostava etmosfernyih osadkov $v$ razlichnyih fiziko-geograficheskih zonah USSR [On the formation of the chemical composition of atmospheric precipitation in various physico-geographical zones of the USSR]. Fizicheskaya geografiya i geomorfologiya. 21, 126-131.(in Russian).

Savitskii V.N., Stets'ko N.S., Osadchii V.I., Khil'chevskii V.K., 1994. Content and distribution of some pollutants in Danube water. Water Resources. 20(4), 462-468.

Sherstiuk N.P., Khilchevskyi V.K., 2012. Osoblyvosti hidrokhimichnykh protsesiv $\mathrm{u}$ tekhnohennykh ta pryrodnykh vodnykh obiektakh Kryvbasu [Features of hydrochemical processes in man-made and natural water objects of Kryvbas]. Aktsent, Dnipropetrovsk (in Ukrainian).

Shestopalov V.V. (editor), 2009. Formuvannia mineralnykh vod Ukrainy [Formation of mineral waters of Ukraine]. Naukova dumka, Kyiv (in Ukrainian).

Skopintsev B.A., 1975. Formirovanie sovremennogo himicheskogo sostava vod Chernogo morya [Formation of the modern chemical composition of the Black Sea waters]. Gidrometeoizdat, Leningrad (in Russian).

Snizhko S.I., 2006. Teoriia i metody analizu rehionalnykh hidrokhimichnykh system [Theory and methods of analysis of regional hydrochemical systems]. Nika-Tsentr, Kyiv (in Ukrainian).

Vodnyi kodeks Ukrainy, 1995 (z dopovnenniamy iz 2000 r.) [The Water Code of Ukraine, 1995 (with amendments from 2000 year] (in Ukrainian). Retrieved from http://zakon2.rada.gov.ua/laws/show/213/95$\% \mathrm{D} 0 \% \mathrm{~B} 2 \% \mathrm{D} 1 \% 80$.

Vodnyi fond Ukrainy: Shtuchni vodoimy vodoskhovyshcha i stavky, 2015. [Water Fund of Ukraine. Artificial reservoirs - reservoirs and ponds]. Interpres, Kyiv(in Ukrainian).

Zabokrytska M.R., Khilchevskyi V.K., Manchenko A.P., 2006. Hidroekolohichnyi stan baseinu Zakhidnoho Buhu na terytorii Ukrainy [Hydroecological state of the basin of the Western Bug on the territory of Ukraine]. Nika-Tsentr, Kyiv (in Ukrainian).

Zakrevskyi D.V., 1992. Otsenka vliyaniya osushitelnyih melioratsiy na himicheskiy sostav rechnyih vod [Assessment of the influence of drainage melioration on the chemical composition of river water]. Melyoretsyia y vodnoe khoziaistvo. 76, 66-71 (in Russian).

Zakrevskii D.V., Peleshenko V.I., Khil'chevskii V.K., 1988. Dissolved load of Ukrainian rivers. Water Resources. 15(6), 547-557.

Zhuravleva L.A., 1989. Gidrohimiya ustevoy oblasti Dnepra i Yuzhnogo Buga v usloviyah zaregulirovannogo rechnogo stoka [Hydrochemistry of the estuary region of the Dnieper and the Southern Bug in conditions of regulated river flow]. Naukova dumka, Kiev (in Russian). 